\title{
ROLA WOJSK SPECJALNYCH W SYSTEMIE OBRONNYM RP
}

Wojska specjalne, we współczesnym rozumieniu tego pojęcia, wykształciły się w okresie II wojny światowej. W czasie zimnej wojny ich rozwój w ramach sił zbrojnych czołowych mocarstw militarnych przebiegał z różną intensywnością. Dopiero koniec zimnej wojny oraz nowe międzynarodowe środowisko bezpieczeństwa, które ukształtowało się w latach dziewięćdziesiątych XX w. zapoczątkowały dynamiczny rozwój tego rodzaju wojsk w wielu państwach (przede wszystkim w USA oraz innych państwach członkowskich NATO). Wydarzenia 11 września 2001 r. i będąca ich konsekwencją tzw. ,globalna wojna z terroryzmem” dodatkowo wzmocniły ten trend, umacniając pozycję wojsk specjalnych jako jednego z kluczowych, militarnych narzędzi polityki bezpieczeństwa państw sojuszniczych. W Polsce jednostki specjalne powstały już w okresie PRL, jednak ich zdolności i użyteczność w pełni doceniono dopiero w okresie po 1989 r. Od początku XXI w. polskie siły specjalne przeżywają okres dynamicznego rozwoju. Jego wyrazem jest powołanie Wojsk Specjalnych jako osobnego, czwartego, rodzaju sił zbrojnych.

Celem tego artykułu jest ukazanie roli, jaką Wojska Specjalne pełnią obecnie i mogą pełnić w przyszłości w ramach systemu obronnego RP ${ }^{1}$. W tym celu zostaną przedstawione ich unikalne cechy, wyróżniające je spośród innych rodzajów wojsk. Pokrótce omówiona zostanie również historia, zadania i potencjał jednostek podległych Dowództwu Wojsk Specjalnych (DWS). Najistotniejszym elementem z punktu widzenia realizacji nakreślonego wcześniej celu artykułu będzie analiza przydatności WS dla realizacji misji Sił Zbrojnych RP wymienionych w Doktrynie Obronności z 2009 roku².

1 System obronny państwa stanowi skoordynowany zbiór elementów kierowania i elementów wykonawczych, a także realizowanych przez nie funkcji i procesów oraz zachodzących między nimi relacji. SOP tworzą wszystkie siły i środki przeznaczone do realizacji zadań obronnych, odpowiednio do tych zadań zorganizowane, utrzymywane i przygotowywane. Organizacja i funkcjonowanie SOP oparte jest na przepisach prawa powszechnie obowiązującego, a także na postanowieniach wynikających z umów i traktatów międzynarodowych, których Polska jest stroną (Strategia, 2009: 12).

2 W okresie, gdy rozpoczęto przygotowywanie tego artykułu (druga połowa 2012 r.) obowiązywała Strategia Obronności RP (SO) z 2009 r. 9 kwietnia 2013 r. Rada Ministrów przyjęła Strategię Rozwoju Systemu Bezpieczeństwa Narodowego RP 2022 (SRSBNRP), która zastapiła wcześniejszą SO. Warto jednak zauważyć, iż SRSBNRP również posługuje się pojęciem Systemu Obronnego Państwa. Można w tym miejscu przytoczyć następujące zapisy tego dokumentu: „W sensie prawnym system bezpieczeństwa narodowego nie stanowi zatem, funkcjonującej samodzielnie struktury państwowej. Zasadniczą formą jego organizacji i działania pozostaje system obronny państwa (SOP), utrzymywany w celu zapewnienia ochrony żywotnych interesów narodowych, a w szczególności suwerenności i niepodległości narodu polskiego, jego prawa do integralności terytorialnej i nie- 
Tytułem wniosków zostaną krótko scharakteryzowane szanse, wyzwania, ryzyka i zagrożenia związane z dalszym rozwojem polskich wojsk specjalnych.

\section{WOJSKA SPECJALNE - SPECYFIKA}

Zarówno w oficjalnych dokumentach, jak i w literaturze funkcjonują różne definicje sił specjalnych. Już samo nazewnictwo tego rodzaju wojsk jest dość istotnie zróżnicowane. Używa się takich określeń jak: „siły specjalne”, „siły operacji specjalnych” $\left(\mathrm{USA}^{3}\right)$, „siły specjalnego przeznaczenia”. Na potrzeby tego artykułu przyjęto oficjalne polskie nazewnictwo wojskowe tj. „wojska specjalne”. Zgodnie z definicją zawartą w stosownych dokumentach doktrynalnych NATO: „Siły Operacji Specjalnych to wyznaczone aktywne lub rezerwowe siły składowe narodowych sił zbrojnych specjalnie zorganizowane, wyszkolone $\mathrm{i}$ wyposażone do prowadzenia i wsparcia operacji specjalnych” (NATO, 2008: 9). Natomiast same „operacje specjalne” według oficjalnego słownika NATO to: „działania wojskowe prowadzone przez specjalnie wyznaczone, zorganizowane, wyszkolone i wyposażone siły, używające technik operacyjnych i trybów użycia niestandardowych dla sił konwencjonalnych. Działania te są prowadzone w całym zakresie operacji wojskowych, niezależnie lub w koordynacji z operacjami sił konwencjonalnych, dla osiagnięcia celów politycznych, wojskowych, psychologicznych i gospodarczych. Uwarunkowania polityczno-militarne mogą wymagać tajnych, skrytych lub dyskretnych technik oraz akceptacji fizycznego i politycznego ryzyka na poziomie nie związanym z operacjami konwencjonalnymi" (ibidem: 5). Trafna wydaje się być również spotykana w literaturze definicja, określająca siły specjalne jako: „małe liczebnie, specjalnie wyselekcjonowane, wyszkolone i wyposażone pododdziały sił zbrojnych realizujące na poziomie taktycznym operacje mające wpływ na sytuację operacyjną i strategiczną" (Odpowiednie, 2012: 31).

naruszalności granic” (Strategia, 2013: 14); oraz „Będzie on [zintegrowany system bezpieczeństwa narodowego] nadal rozwijany w oparciu o jego dwa zasadnicze elementy: system obronny państwa i system zarządzania kryzysowego" (Strategia, 2013: 33). Trzy zasadnicze misje Sił Zbrojnych RP nakreślone w SO również pojawiają się w SRSBNRP: „Siły Zbrojne RP są podstawowym elementem systemu obronnego państwa. Unikalne w skali państwa zdolności czynią z sił zbrojnych wielofunkcyjne narzędzie do wypełniania szerokiego spektrum misji, do których należą: zagwarantowanie obrony państwa i przeciwstawienie się agresji w ramach zobowiązań sojuszniczych, udział w stabilizowaniu sytuacji międzynarodowej oraz wspieranie bezpieczeństwa wewnętrznego i pomoc społeczeństwu” (Strategia, 2013: 18). W ramach drugiego celu operacyjnego SRSBNRP „Umacnianie zdolności państwa do obrony” określa się następujące misje SZ RP: „Zapewnienie zdolności państwa do obrony oraz przeciwstawienia się agresji w ramach zobowiązań sojuszniczych”, „Udział Sił Zbrojnych RP w stabilizowaniu sytuacji międzynarodowej” oraz „Udzielanie pomocy wojskowej organom państwa w niemilitarnych sytuacjach kryzysowych" (Strategia, 2013: 52-56). Wobec powyższych faktów autor zdecydował się na pozostawienie w tekście odniesień do Doktryny Obronności z 2009 r. ze względu na ich aktualność w kontekście zapisów SRSBNRP 2022 przyjętej w 2013 r.

3 W USA nazwa „siły specjalne” (ang. Special Forces) jest używana przez jedną konkretną formację - US Army Special Forces (znanej potocznie jako „Zielone Berety”). Stąd ogół jednostek specjalnych, podporządkowanych Dowództwu Operacji Specjalnych (ang. United States Special Operations Command - USSOCOM) określa się mianem Sit Operacji Specjalnych. 
Aby odpowiedzieć na pytanie: „co wyróżnia wojska specjalne spośród innych rodzajów wojsk?"; można podjąć próbę syntezy elementów pojawiających się w większości funkcjonujących definicji. Należy zatem zwrócić uwagę, iż odrębność wojsk specjalnych przejawia się na trzech płaszczyznach: wykonywanych misji, metod działania oraz potrzebnych do tego środków.

Omówienie misji wykonywanych przez wojska specjalne można rozpocząć od przedstawienia (dla ilustracji) kategorii zadań przewidzianych dla tych sił w NATO (ponieważ doktryna sojusznicza w znacznym stopniu kształtuje polską politykę obronną, także w odniesieniu do operacji specjalnych) oraz w siłach zbrojnych USA (z uwagi na unikatową skalę struktur i doświadczenia tego państwa w zakresie operacji specjalnych, przez co stało się ono swoistym wzorem dla innych państw rozwijających wojska specjalne). Doktryna NATO przewiduje trzy zasadnicze misje sojuszniczych sił specjalnych: Rozpoznanie Specjalne (ang. Special Reconnaissance - SR), Akcje Bezpośrednie (ang. Direct Action - DA) oraz Wsparcie Wojskowe (ang. Military Assistance-MA) (NATO, 2008: C1).

Katalog zasadniczych zadań amerykańskich sił operacji specjalnych jest znacznie szerszy. Obejmuje on:

- akcje bezpośrednie - „krótkotrwałe uderzenia oraz inne akcje ofensywne na małą skalę dla opanowania, zniszczenia, schwytania lub odzyskania [celów] na obszarach zabronionych";

- rozpoznanie specjalne - „pozyskiwanie informacji odnośnie zdolności, intencji i działan przeciwnika";

- walkę niekonwencjonalną (ang. Unconventional Warfare - UC) - „operacje prowadzone przez, za pośrednictwem oraz wspólnie z siłami zastępczymi, które są organizowane, szkolone, wyposażane, wspomagane i kierowane przez siły zewnętrzne";

- tzw. obronę wewnętrzną państw trzecich (ang. Foreign Internal Defence - FID) - ,zapewnianie szkolenia i innego wsparcia rządom państw trzecich oraz ich siłom zbrojnym dla umożliwienia rządom państw trzecich zapewnienia bezpieczeństwa narodowego";

- operacje cywilno-wojskowe (ang. Civil Affairs Operations - CAO) - ,działania, które ustanawiaja, podtrzymują lub wpływają na stosunki między siłami USA a zagranicznymi władzami cywilnymi oraz populacjami cywilnymi dla ułatwienia operacji wojskowych USA";

- przeciw-terroryzm (ang. Counterterrorism - CT) - ,środki podejmowane dla zapobiegania, odstraszania oraz reagowania na terroryzm";

- operacje psychologiczne (ang. Psychological Operations - PsyOps) - „operacje polegające na dostarczaniu zagranicznym odbiorcom prawdziwych informacji, dla kształtowania zachowań w ramach wsparcia operacji wojskowych USA";

- operacje informacyjne (ang. Information Operations - IO) - „operacje zaplanowane w celu uzyskania przewagi informacyjnej przez negatywny wpływ na informacje i systemy nieprzyjaciela przy jednoczesnej ochronie informacji i systemów USA";

- przeciw-proliferacja broni masowego rażenia (ang. Counter-Proliferation of Weapons of Mass Destruction - CPWMD) - „działania podejmowane w celu lokalizacji, zajęcia, zniszczenia lub pochwycenia, odzyskania i uczynienia tego rodzaju broni bezpieczną"; 
- wsparcie sił bezpieczeństwa (ang. Security Forces Assistance - SFA) - „zjednoczone działania podejmowane przez wspólną, międzyresortową, międzyrządową i wielonarodową wspólnotę dla podtrzymania i wsparcia państwa gospodarza lub regionalnych sił bezpieczeństwa w ramach pomocy dla legalnej władzy"; oraz

- operacje przeciwpartyzanckie (ang. Counterinsurgency Operations - COIN) - „,wojskowe, paramilitarne, polityczne, ekonomiczne, psychologiczne i cywilne działania podejmowane przez rząd w celu pokonania partyzantki" (US SOCOM).

Naturalnie przedstawione powyżej zestawienia nie wyczerpują całości katalogu misji, które są lub mogą być powierzane wojskom specjalnym. Warto także pamiętać, iż na przestrzeni lat katalog szczegółowych zadań powierzanych tym formacjom ulegał zmianom. Podejmując próbę pewnej generalizacji, mającej na celu zdefiniowanie wojsk specjalnych poprzez wypełniane przez nie misje, należałoby zwrócić uwagę na trzy kwestie. Po pierwsze, jednostkom specjalnym powierza się wykonywanie zadań, których nie są w stanie w pełni zrealizować siły konwencjonalne. Może to wynikać z braków doktrynalnych, szkoleniowych lub sprzętowych występujących w wojskach konwencjonalnych (będących efektem ich miejsca i roli w strukturze sił zbrojnych, a nie ich „niższej jakości”).

Według Roberta G. Spulaka Jr. możliwości bojowe wojsk są ograniczane przez Clausewitzowskie „tarcie”, które wypływa z trzech zasadniczych przyczyn: ludzkich ograniczeń psychicznych i fizycznych, niepewności informacyjnej i nieprzewidywalnych różnic między postrzeganiem rzeczywistości a jej faktycznym stanem oraz strukturalnej nielinearności procesów bojowych (mówiąc inaczej ich wysokiej komplikacji prowadzącej do nieprzewidywalności). W opinii cytowanego autora, wojska specjalne są szczególnie predestynowane do przezwyciężenia trzech wspomnianych wcześniej źródeł „tarcia” ze względu na swe integralne cechy. Ponieważ żołnierze jednostek specjalnych są „elitarnymi wojownikami”, łatwiej przychodzi im przezwyciężanie ludzkich ograniczeń fizycznych i psychicznych. Integralna elastyczność jednostek specjalnych, wynikająca chociażby z szerokiego wachlarza zdolności reprezentowanych przez ich członków znacząco ułatwia im przeniknięcie „mgły wojny” i prawidłowe rozeznanie się w sytuacji. Natomiast w odniesieniu do nieprzewidywalności walki, jedną z kluczowych charakterystyk wojsk specjalnych jest kreatywność, tj. zdolność dowódców (jak również szeregowych żołnierzy) do tworzenia i zastosowania innowacyjnych rozwiązań złożonych problemów taktycznych i operacyjnych (Spulak, 2007: 19-21).

Po drugie, wojska specjalne wykonują zadania o znaczeniu operacyjnym i strategicznym. Zgodnie z koncepcją która upowszechniła się w państwach NATO, jednostki specjalne, mimo relatywnie niewielkiej skali prowadzonych działań powinny osiagać za ich pomocą efekty decydujące o powodzeniu, jeśli nie całego konfliktu to przynajmniej konkretnej operacji czy kampanii. Stąd nieprzypadkowe wydaje się wprowadzenie do polskiej terminologii wojskowej określenia „operacje specjalne” w miejsce wcześniejszych „działań specjalnych”, co podkreśla ich wyższą rangę i istotny wkład w ogólny wysiłek zbrojny. W myśl tej logiki, jednostki specjalne powinno się angażować do działań niosących ze sobą perspektywę ponadprzeciętnych ,zysków” militarnych (Odpowiednie, 2012: 34). Ostatnim elementem definiującym misje wojsk specjalnych jest fakt, iż operacje specjalne są prowadzone w czasie pokoju, kryzysu i wojny. Kontrastu- 
je to ze sposobem działania wojsk konwencjonalnych, które zasadniczo w czasie pokoju się szkolą, podejmują zasadnicze operacje w czasie kryzysu i w pełni rozwijają je w okresie wojny. Natomiast jednostki specjalne mogą wypełniać zadania z przedstawionego wcześniej katalogu (jak np. szkolenie partnerów, wspieranie sił bezpieczeństwa, czy rozpoznanie) w każdym z tych stanów. Stanowią one również istotne narzędzie polityki bezpieczeństwa państwa, po które często w pierwszej kolejności sięga się w wypadku zaistnienia kryzysu.

Kolejnym obszarem definiującym wojska specjalne są metody działania. Niekonwencjonalna taktyka, mocno odbiegająca od tradycyjnych form walki stosowanych w regularnych siłach zbrojnych, w największym stopniu określa charakter jednostek specjalnych i wyróżnia je spośród innych rodzajów wojsk. W całej historii działań i operacji specjalnych rację bytu tego typu formacji stanowiło osiaganie wysokiej skuteczności dzięki zastosowaniu niestandardowych metod prowadzenia walki (np. wojny partyzanckiej, działań dywersyjno-sabotażowych lub patrolowych na terytorium przeciwnika czy operacji odbijania zakładników). Należy również zwrócić uwagę na wspomnianą już wysoką elastyczność i kreatywność żołnierzy formacji specjalnych pozwalające im na szybkie dostosowywanie się do nowych uwarunkowań. Wojska specjalne są często pionierami nowych rozwiązań taktycznych i technik działania. Istotną cechą operacji specjalnych jest również ich tajny charakter. Standardowe procedury bezpieczeństwa operacyjnego są $\mathrm{w}$ jednostkach specjalnych znacznie bardziej rozbudowane niż w wojskach konwencjonalnych. Wojska specjalne często wykorzystywane są w sytuacjach, gdy dane państwo chce ukryć swoje zaangażowanie w danym konflikcie. Stąd konieczność szczególnej skrytości działań oraz stosowania rozbudowanych technik maskowania.

Ostatnią płaszczyznę decydującą o odrębności wojsk specjalnych stanowią dostępne im zasoby. Mowa w tym wypadku o zasobach ludzkich, materiałowych oraz ich organizacji. Jednym z najważniejszych elementów określających specyficzną „kulturę” wojsk specjalnych jest przekonanie o decydującej roli czynnika ludzkiego znajdujące odbicie w lakonicznym stwierdzeniu, iż „w Wojskach Specjalnych ludzie są ważniejsi niż sprzęt, a jakość ważniejsza niż ilość" (Kwasek, 2012: 86). O wartości bojowej każdej jednostki wojskowej w zasadniczym stopniu decyduje poziom wyszkolenia, zgrania i motywacji tworzących ją żołnierzy. W przypadku formacji specjalnych, ze względu na charakter powierzanych im misji oraz specyficzne metody wykorzystywane do ich realizacji, czynniki te odgrywają jeszcze większą rolę. Służba w jednostkach specjalnych wymaga specyficznego zestawu cech psychofizycznych oraz umiejętności, których rozkład w ogólnej puli personelu wojskowego jest nierównomierny. Stąd jednym z najważniejszych elementów procesu formowania i utrzymywania wojsk specjalnych jest rygorystyczna selekcja kandydatów do służby (Spulak, 2007: 10-14). Praktycznie w każdych siłach zbrojnych jednostki specjalne są uważane za elitę, a służba w nich wiąże się z wysokim prestiżem.

W znacznie mniejszym stopniu wojska specjalne są określane przez specjalistyczne uzbrojenie i wyposażenie. Zazwyczaj jest ono uważane za wtórne w stosunku do specjalistycznego personelu. Nie można jednak pominąć faktu, iż broń oraz inny sprzęt wojskowy (środki transportu, systemy łączności, czujniki, wyposażenie indywidualne żołnierza itp.) używane w jednostkach specjalnych mocno odbiegają od standardów sił 
konwencjonalnych. Charakter operacji specjalnych często wymaga wysoce specjalistycznego wyposażenia. Przykładowo, w wielu siłach zbrojnych formacje specjalne znajdują się w ścisłej czołówce (pod względem umiejętności i sprzętu) w takich obszarach jak skoki spadochronowe czy nurkowanie. Najczęściej wojska specjalne jako pierwsze otrzymują nowe wzory uzbrojenia i wyposażenia, niejednokrotnie już na etapie testowania nowych rozwiązań. Zauważalnym trendem jest również przyznawanie jednostkom specjalnym szerokiej autonomii w zakresie zakupów nowego i/lub nietypowego wyposażenia. Dlatego też można w nich często spotkać modele broni i sprzętu unikalne w skali sił zbrojnych.

Wojska specjalne posiadają również specyficzną strukturę organizacyjną. Z uwagi na zarysowane wcześniej uwarunkowania są one stosunkowo nieliczne (stanowiące najczęściej zaledwie kilka procent ogółu sił zbrojnych) ${ }^{4}$. Do kluczowych elementów kultury organizacyjnej sił specjalnych należy zasada, iż „Wojska Specjalne nie są produktem masowym" (Kwasek, 2012: 86). Operacje specjalne są zazwyczaj realizowane przez niewielkie, autonomiczne zespoły dysponujące szerokim wachlarzem zdolności. Ważnym aspektem funkcjonowania jednostek specjalnych jest ich specyficzne umocowanie w strukturze organizacyjnej sił zbrojnych. Zazwyczaj są one bezpośrednio podporządkowane najwyższemu dowództwu lub dowódcom rodzajów sił zbrojnych. W ostatnich latach w NATO upowszechniono model osobnych struktur odpowiedzialnych za dowodzenie i kierowanie operacjami specjalnymi (zazwyczaj w formie osobnego dowództwa operacji specjalnych) (NATO, 2008: 2-3).

\section{POLSKIE WOJSKA SPECJALNE}

W Polsce Wojska Specjalne stały się osobnym rodzajem sił zbrojnych 24 maja 2007 r. (DWS , a). Wcześniej, 25 października 2006 r. powołano Dowództwo Wojsk Specjalnych (DWS, b). Jako jedyne w Siłach Zbrojnych RP odpowiada ono zarówno za przygotowanie wojsk (pod kątem szkoleniowym, organizacyjnym i doktrynalnym), jak również za bezpośrednie dowodzenie operacyjne - tj. według terminologii NATO jest zarówno „force provider”, jak i „force user” (Cielma, 2012: 28). Wojska Specjalne stanowią obecnie (stan na koniec 2012 r.) ok. 3\% liczebności ogółu Sił Zbrojnych RP. Biorąc pod uwagę, iż Wojsko Polskie liczy obecnie ok. 100000 żołnierzy, można założyć, iż w najmłodszym rodzaju sił zbrojnych pełni służbę ok. 3000 ludzi. Na Wojska Specjalne przypada również ok. 2,75\% budżetu MON (projekt budżetu resortu na 2013 r. zakłada, iż wojska specjalne będą miały do dyspozycji $311 \mathrm{mln}$ zł, oznacza to wzrost o 4\% w porównaniu z rokiem poprzednim (Palowski, 2012: 4). Warto również podkreślić skalę zaangażowania WS w operację w Afganistanie. Formacje podległe DWS wystawiają dwa zespoły zadaniowe, które stanowią ok. 8\% ogólnej liczebności Polskiego Kontyngentu Wojskowego Afganistan, jednak wykonują one ok. 30\% ogółu „operacji kinetycznych”. O skali rozwoju Wojsk Specjalnych może świadczyć fakt, iż w chwili ich powołania (jako osobnego RSZ) stanowiły one zaledwie 1,5\% liczebności

4 Przykładowo 3,8\%w USA (Spulak, 2007: 12), 3\% w Polsce (DWS a). 
SZ RP (do roku 2012 podwojono liczbę zespołów bojowych). Dysponowały one również zaledwie 1,8\% budżetu MON. Ważnym osiągnięciem nowych struktur było również przyjęcie Połaczonej Doktryny Operacji Specjalnych (Kwasek, 2012: 86; Reforma, 2012: 35).

W skład Wojsk Specjalnych wchodzi obecnie 5 Jednostek Wojskowych (JW): $J W$ GROM, JW Komandosów, JW Formoza, JW Nil, JW Agat. W trakcie formowania znajduje się 7 eskadra działań specjalnych, która będąc częścią Sił Powietrznych ma zapewniać wsparcie lotnicze dla operacji specjalnych (Kwasek, 2012: 88).

JW GROM (Grupa Reagowania Operacyjno-Manewrowego) została powołana do życia 13.07.1990 r. Początkowo była ona podporządkowana Ministerstwu Spraw Wewnętrznych (pod kontrolę MON przeszła w 1999 r.). Od samego początku tworzono ją jako jednostkę antyterrorystyczną przeznaczoną w pierwszej kolejności do działań w sytuacjach kryzysowych poza granicami państwa. Spośród wszystkich polskich jednostek specjalnych GROM posiada największe doświadczenie bojowe i jest uważana za najbardziej elitarną. Obecnie jest to wszechstronna jednostka przygotowana do prowadzenia zarówno operacji anty- i kontrterrorystycznych, jak i klasycznych wojskowych operacji specjalnych, na lądzie i morzu. W jej skład wchodzą trzy zespoły bojowe (w tym jeden wodny) (JW GROM; Rybak, 2009).

JW Komandosów wywodzi się z 1 Pułku Specjalnego (później 1 Pułku Specjalnego Komandosów). Przed powstaniem DWS Pułk znajdował się w strukturach Wojsk Lądowych. Formacja ta powstała na początku lat dziewięćdziesiątych XX w. na bazie personelu Batalionu Szturmowego i Kompanii Specjalnych funkcjonujących w Ludowym Wojsku Polskim. Specjalnością JW Komandosów są klasyczne wojskowe operacje specjalne prowadzone na lądzie (rozpoznanie specjalne, akcje bezpośrednie, wsparcie militarne, działania niekonwencjonalne). Obecnie w skład jednostki wchodzą trzy zespoły bojowe (JW Komandosów; Krugler 2009: 14-15).

JW Formoza wywodzi się ze sformowanej w 1975 r. jednostki specjalnej płetwonurków Marynarki Wojennej. Bezpośrednio przed powstaniem DWS funkcjonowała ona w strukturach MW jako Grupa Specjalna Ptetwonurków. Po przejściu w podporządkowanie DWS przyjęła nazwę Morskiej Jednostki Działań Specjalnych, obecnie JW Formoza. Pojedynczy zespół bojowy tej jednostki specjalizuje się w morskich i śródlądowych operacjach specjalnych, chociaż w ostatnich latach czyni się starania na rzecz pełnego przystosowania jednostki do prowadzenia działań lądowych (np. w ramach operacji w Afganistanie) (JW Formoza; Chloupek, 2010b: 8-24).

JW Nil powstała w 2008 r. jako Jednostka Wsparcia Dowodzenia i Zabezpieczenia Wojsk Specjalnych. Do jej obowiązków należy zapewnienie systemu dowodzenia, wsparcia informacyjnego (wywiadowczego) oraz zabezpieczenie logistyczne operacji specjalnych.

Najmłodszą jednostką Wojsk Specjalnych jest JW Agat, powołana do życia w $2011 \mathrm{r}$. na bazie kadry rozwiązanego Oddziału Specjalnego Żandarmerii Wojskowej w Gliwicach. Zasadniczym przeznaczeniem dwóch zespołów bojowych wchodzących w jej skład jest zapewnienie wsparcia bojowego dla operacji specjalnych (stąd wysokie nasycenie ciężką bronią wsparcia). Oprócz tego mogą one również prowadzić działania przeciwdywersyjne i przeciwpartyzanckie oraz zabezpieczać infrastrukturę krytyczną (Krugler, 2012: 10-12). 


\section{MISJE SIL ZBROJNYCH RP A ZDOLNOŚCI WOJSK SPECJALNYCH}

Strategia Obronności RP z 2009 r. stawia przed Siłami Zbrojnymi RP trzy zasadnicze misje: zagwarantowanie obrony państwa i przeciwstawienie się agresji; udział $\mathrm{w}$ procesie stabilizacji sytuacji międzynarodowej oraz w operacjach reagowania kryzysowego i humanitarnych oraz wspieranie bezpieczeństwa wewnętrznego i pomoc społeczeństwu (Strategia, 2009: 16). Chociaż zadania związane z obroną terytorium RP przed potencjalną agresją są uważane za priorytetowe, to biorąc pod uwagę obecną aktywność SZ RP oraz prognozy odnośnie przyszłego środowiska bezpieczeństwa - zawarte na przykład w Wizji SZ RP 2030 (Wizja: 7-13) można uznać, iż udział w konflikcie zbrojnym na własnym terytorium jest uznawany, w dającej się przewidzieć przyszłości, za mało prawdopodobny. Stąd priorytetową misją Wojska Polskiego jest udział w międzynarodowych misjach ekspedycyjnych, co potwierdzają doświadczenia ostatnich dziesięciu lat. Z tego względu w pierwszej kolejności analizie zostanie poddana użyteczność Wojsk Specjalnych w warunkach konfliktu asymetrycznego towarzyszącego współcześnie misjom ekspedycyjnym pod kontrolą NATO, UE i ONZ.

\section{Udział w procesie stabilizacji sytuacji międzynarodowej oraz w operacjach reagowania kryzysowego $i$ humanitarnych}

Wojska Specjalne, z uwagi na swoje unikalne zdolności, są szczególnie predestynowane do prowadzenia działań niekonwencjonalnych i przeciwpartyzanckich $\mathrm{w}$ trakcie konfliktów asymetrycznych. Joe Celeski analizuje trzy scenariusze działań, w które mogą zostać zaangażowane siły operacji specjalnych: walkę polityczną (przemoc polityczna poniżej progu wojny), wojnę nieregularną oraz wojnę konwencjonalną. W jego opinii użycie sił operacji specjalnych przynosi największe korzyści strategiczne w dwóch pierwszych przypadkach. W toku walki politycznej oraz wojny nieregularnej wojska specjalne moga odgrywać kluczową rolę w realizacji celów strategicznych, natomiast $\mathrm{w}$ trakcie wojny konwencjonalnej raczej wspierają i uzupełniają one działania wojsk konwencjonalnych. W tym ostatnim scenariuszu efekty użycia wojsk specjalnych mają coraz mniejszą wartość strategiczną i przybierają w większym stopniu charakter taktyczny (Joint, 2011: 22-24). Specyficzne zdolności wojsk specjalnych decydują o ich użyteczności w kontekście misji ekspedycyjnych na dwóch płaszczyznach - polityczno-strategicznej decyzji o zaangażowaniu w konflikt oraz właściwych operacji wojskowych.

W odniesieniu do płaszczyzny polityczno-strategicznej należy zauważyć, iż dla większości państw członkowskich NATO i UE zaangażowanie w operacje ekspedycyjne (jak np. w Iraku, Afganistanie, Libii czy Mali) nie jest kwestią obrony żywotnych interesów narodowych. Stąd decyzja o zaangażowaniu jest zazwyczaj poprzedzona skrupulatną kalkulacją strategicznych kosztów i efektów udziału w konflikcie. W tym kontekście użycie wojsk specjalnych jest (szczególnie w polskim kontekście) atrakcyjną opcją. Wynika to z takich ich cech jak: ekonomia wysiłku, interoperacyjność z siłami sojuszniczymi oraz wysoka gotowość.

Jak już wcześniej zaznaczono udział w operacjach ekspedycyjnych nie jest dla wielu państw sojuszniczych (w tym Polski) kwestią obrony najżywotniejszych interesów 
bezpieczeństwa narodowego. Można nawet postawić tezę, iż jednym z istotnych czynników motywujących je do udziału w tego typu przedsięwzięciach jest chęć zademonstrowania solidarności sojuszniczej. Mówiąc dosadniej, państwa takie jak Polska, wysyłając swoich żołnierzy na odległe teatry działań dążą między innym do udowodnienia swej przydatności dla kluczowych sojuszników (zwłaszcza USA), aby w sytuacji zagrożenia własnych kluczowych interesów móc liczyć na ich pomoc. Tym samym kwestia kosztów (tak finansowych, jak i politycznych) takiego zaangażowania staje się ważnym czynnikiem rzutującym na planowanie strategiczne i operacyjne. Tworzenie i utrzymywanie wojsk specjalnych jest kosztowne jednak w porównaniu z innymi rodzajami wojsk relacje koszt/efekt mogą być korzystne. Autorzy studium przygotowanego dla NATO oceniają koszty utworzenia i pełnego wyekwipowania lądowej jednostki specjalnej o liczebności 110 ludzi na 13 milionów euro. W przypadku 250-osobowej morskiej jednostki specjalnej koszty pełnego wyposażenia oszacowano na 26 milionów euro. Dla porównania jeden wielozadaniowy samolot bojowy Eurofighter Typhoon kosztuje 77 milionów euro, śmigłowiec typu $\mathrm{NH}-90$ - 16 milionów euro, samolot transportowy $A 400 M-100$ milionów euro, a fregata typu FREMM - 342 miliony euro (NATO, 2008: 31).

Odwołując się do polskich doświadczeń, można wspomnieć o udziale żołnierzy GROM w sojuszniczych operacjach w regionie Zatoki Perskiej w latach 2002-2004. W tym okresie jednym z zasadniczych elementów PKW operującego w Zatoce Perskiej był 20-50-osobowy zespół żołnierzy jednostki GROM. Wykonywał on ważne zadania z zakresu kontroli żeglugi, a później (już w ramach operacji Iraqi Freedom) wypełniał misje opanowania obiektów o znaczeniu strategicznym. Działania te spotkały się z uznaniem ze strony amerykańskich partnerów, zarówno ze względu na sprawność ich wykonania, jak i znaczenie dla ogólnego wysiłku koalicyjnego (Rybak, 2009: 51-57, 101-102, 191-305). Próbując wyciagnąć z tych doświadczeń wnioski można by zauważyć, iż wysłanie w rejon operacji kilkudziesięcioosobowego zespołu zadaniowego wojsk specjalnych jest rozwiązaniem obarczonym znacznie mniejszymi kosztami finansowymi i ryzykiem politycznym niż utrzymywanie wielotysięcznego kontyngentu wojsk konwencjonalnych. Jednocześnie, mimo niewielkiej liczebności, zespół taki może wnieść znaczący wkład w operacje koalicyjne, co pozwala dyskontować polityczne korzyści zaangażowania. Należy jednak pamiętać, iż nie w każdej operacji kontyngent narodowy może zostać oparty wyłącznie (a nawet głównie) na wojskach specjalnych.

Dodatkowym czynnikiem decydującym o użyteczności jednostek specjalnych z punktu widzenia polityczno-strategicznej decyzji o zaangażowaniu w misję ekspedycyjną jest wysoki poziom gotowości bojowej stale utrzymywany przez tego typu formacje oraz ich zdolności i doświadczenie w zakresie współpracy z siłami wielonarodowymi. Doskonałą ilustrację może stanowić udział GROM w misji międzynarodowej na Haiti w 1994 r. Jednostka ta była gotowa do działania w krótkim czasie, jak również posiadała kwalifikacje i doświadczenie w zakresie współpracy z wojskami innych państw (przede wszystkim USA). Dekada zaangażowania w operacje zagraniczne oraz dostosowywania się do wymagań NATO i UE (związanych chociażby z udziałem polskich jednostek w formacjach wysokiej gotowości obu organizacji) przyczyniła się do znacznego postępu w obrębie sił konwencjonalnych w zakresie poziomu gotowości do udziału w misjach poza granicami państwa, jak również interoperacyjności w ramach 
struktur wielonarodowych. Nadal jednak wojska specjalne są liderami SZ RP w obu tych obszarach.

Unikalne zdolności wojsk specjalnych czynią ten rodzaj wojsk nadzwyczaj użytecznym komponentem operacji wojskowych w warunkach konfliktu asymetrycznego. Na samym wstępie rozważań nad tym zagadnieniem należy zwrócić uwagę, iż występują istotne podobieństwa między organizacją, sposobem działania, a nawet pewnymi elementami kultury organizacyjnej jednostek specjalnych a analogicznymi atrybutami nieregularnych grup zbrojnych będących ich adwersarzami. Przeciwnik asymetryczny posiada zazwyczaj kompaktowa, wysoce elastyczną strukturę. Prowadzi również dynamiczne działania manewrowe oparte na zaskoczeniu i niekonwencjonalnej taktyce. Zarówno dowódcy, jak i szeregowi członkowie organizacji zbrojnych często wykazują się kreatywnością i nieszablonowym myśleniem. Łatwo zauważyć, iż wojska specjalne wykazują podobne cechy. Można zatem założyć, iż będzie im łatwiej walczyć z nieregularnym przeciwnikiem niż wojskom konwencjonalnym z ich bardziej tradycyjną organizacją i doktryną. Jak już wcześniej nadmieniono, jednym z unikalnych obszarów działań wojsk specjalnych jest organizacja, szkolenie i współpraca z siłami lokalnymi (określana w USA jako walka niekonwencjonalna). Z punktu widzenia obecnej, koalicyjnej doktryny i praktyki wojny przeciwpartyzanckiej jest to zdolność kluczowa dla osiagnięcia sukcesu. Przykładowo w Afganistanie, wobec bliskiego terminu wycofania większości zachodnich sił bojowych, ogromny nacisk kładzie się na szkolenie i przygotowanie do samodzielnego działania Afgańskich Sit Bezpieczeństwa. Podobny charakter miały działania w Iraku. Z kolei pierwsza faza działań w Afganistanie (do momentu obalenia reżimu Talibów), jak również operacje prowadzone w trakcie wojny domowej w Libii, pokazują, iż w sprzyjających warunkach, zaangażowanie w lokalne konflikty można ograniczyć do zapewnienia odpowiedniego wsparcia i organizacji siłom miejscowym (jak Sojusz Pótnocny czy libijscy powstańcy) (Gawęda, 2012: 36-45). Stąd duże znaczenie prowadzonych przez wojska specjalne działań z zakresu wsparcia wojskowego i walki niekonwencjonalnej.

Analizując inne kategorie zadań wojsk specjalnych w ramach konfliktu asymetrycznego, należałoby zwrócić uwagę na rozpoznanie specjalne oraz akcje bezpośrednie. Wojska państw NATO i UE dysponują bogatym arsenałem środków i systemów rozpoznania technicznego, które odgrywają istotną rolę w budowie świadomości sytuacyjnej oraz są bardzo wartościowe dla przygotowania i prowadzenia operacji bojowych. Nie można jednak pominąć ich naturalnych ograniczeń, które stają się szczególnie widoczne w trakcie konfliktu asymetrycznego. W sytuacji gdy przeciwnik działa skrycie wśród ludności cywilnej, lub w nadzwyczaj trudnym terenie (jak np. góry Afganista$\mathrm{nu}$ ), tradycyjne formy rozpoznania (np. w postaci patroli dalekiego zasięgu czy posterunków obserwacyjnych) nabierają szczególnego znaczenia. Ponadto w doktrynie przeciwpartyzanckiej szczególny nacisk kładzie się na aspekt ludzki oraz współpracę z miejscową populacją. Stad grupy wojsk specjalnych, które są w stanie swobodnie przemieszczać się wśród oraz komunikować z miejscową ludnością są w stanie dostarczyć (drogą klasycznego wywiadu osobowego - HUMINT - Human Intelligence) cennych informacji, niemożliwych do pozyskania inną droga.

Odnośnie akcji bezpośrednich, zespoły wojsk specjalnych często są wykorzystywane do zatrzymywania lub eliminacji przywódców wrogich grup zbrojnych oraz likwi- 
dowania ich baz czy składów broni. Podobnie jak w obszarze rozpoznania, stanowią tu atrakcyjną alternatywę dla np. ataku lotniczego. Użycie specjalnych sił naziemnych pozwala na pewne potwierdzenie tożsamości/statusu celu, schwytanie osoby lub opanowanie obiektu oraz pełną weryfikację skutków ataku. W przypadku bombardowania lotniczego wszystkie te elementy są wysoce problematyczne. Omyłkowy atak na cele cywilne lub wywołanie „,zniszczeń ubocznych” prowadzi do klęski moralnej, politycznej oraz w efekcie militarnej. Użycie wojsk specjalnych pozwala znacząco ograniczyć ryzyko zaistnienia tego typu sytuacji. Doskonałym przykładem jest amerykańska Operacja Neptun Spear, w ramach której został wyeliminowany Osama bin Laden. Operatorzy Navy SEAL byli w stanie po wejściu do budynku zidentyfikować cel, a następnie wyeliminować go przy relatywnie niewielkich stratach ubocznych, po czym ewakuować się z ciałem poszukiwanego. Bombardowanie lotnicze byłoby być może mniej ryzykowne, ale zapewne nie pozwoliłoby na osiagnięcie opisanych powyżej efektów.

Podsumowując dotychczasowe rozważania można stwierdzić, iż teza o ponadprzeciętnej efektywności wojsk specjalnych w ramach konfliktu asymetrycznego oraz ich dobrym dopasowaniu do jego uwarunkowań strategicznych, operacyjnych i taktycznych znajduje potwierdzenie w doświadczeniach współczesnych konfliktów zbrojnych. W toku tego rodzaju konfliktu siły operacji specjalnych są w stanie osiągać efekty strategiczne, a w szczególnie sprzyjających warunkach operacje specjalne mogą stanowić nawet zasadniczy element prowadzonej kampanii. Można sobie wyobrazić sytuację, w której wojska konwencjonalne stanowią jedynie wsparcie dla operacji prowadzonych przez wojska specjalne. Taka sytuacja praktycznie miała miejsce w pierwszej fazie operacji międzynarodowej w Afganistanie (Joint, 2011: 15).

\section{Zagwarantowanie obrony państwa i przeciwstawienie się agresji}

Realizacja najważniejszej misji SZ RP wiąże się z gotowością do prowadzenia pełnoskalowego konfliktu zbrojnego w obronie RP przed agresją zewnętrzną. Jak już wcześniej wspomniano, historia współczesnych operacji specjalnych sięga czasów II wojny światowej, tj. ostatniego konfliktu konwencjonalnego o zasięgu globalnym. Doświadczenia tej wojny, jak i późniejszych konfliktów, pokazuja, iż wojska specjalne mogą wnieść istotny wkład w konwencjonalne operacje wojskowe. Jednak strategiczne efekty ich użycia są znacznie mniejsze niż w przypadku konfliktu asymetrycznego. Analizując przydatność wojsk specjalnych w konflikcie pełnoskalowym warto zwrócić uwagę na takie kategorie operacji specjalnych jak: rozpoznanie specjalne, akcje bezpośrednie oraz walka niekonwencjonalna.

Zespoły wojsk specjalnych operujące w głębi ugrupowania przeciwnika są w stanie zbierać cenne informacje o położeniu, ruchach i zamierzeniach jego sił. Ważnym elementem tego typu działań może być z pewnością lokalizacja celów o dużym znaczeniu operacyjnym i strategicznym (np. stanowisk dowodzenia, centrów łączności, węzłów logistycznych, mobilnych wyrzutni rakiet balistycznych itp.). W sprzyjających warunkach mogą być one niszczone/unieszkodliwiane na drodze akcji bezpośrednich. W polskich warunkach, warto zauważyć, iż mimo znacznych inwestycji (już poczynionych oraz planowanych), naszego państwa nie stać na pozyskanie i utrzymanie tak rozbudo- 
wanych technicznych systemów rozpoznawczych i uderzeniowych, jakimi dysponują niektórzy nasi sojusznicy. W tej sytuacji rozpoznanie specjalne i akcje bezpośrednie w wykonaniu wojsk specjalnych mogłyby w jakimś stopniu rekompensować te niedostatki. Należy jednak pamiętać, iż w warunkach konfliktu konwencjonalnego, w porównaniu z konfliktem asymetrycznym, prowadzenie tego typu operacji będzie poważnie utrudnione. Obecność licznych, dobrze zorganizowanych i uzbrojonych konwencjonalnych sił przeciwnika poważnie utrudni zapewne przerzut sił specjalnych, wykonanie zadania oraz ewakuację. Kluczowe cele będą zapewne silnie bronione co uczyni zwłaszcza akcje bezpośrednie wysoce ryzykownymi. Można jednak założyć, iż sama obecność grup specjalnych w głębi ugrupowania przeciwnika może skutkować dezorganizacją jego działań oraz związać znaczne siły w ochronie obszarów tyłowych.

Innym ważnym obszarem operacji specjalnych w konflikcie konwencjonalnym może być walka niekonwencjonalna. Nie można wykluczyć, iż w trakcie konfliktu część terytorium RP może znaleźć się pod kontrolą wojsk przeciwnika. W tej sytuacji żołnierze wojsk specjalnych mogliby organizować zbrojny opór na utraconych terenach. Działalność siatek konspiracyjnych i wywiadowczych lub grup dywersyjno-sabotażowych tworzonych w oparciu o żołnierzy rozbitych jednostek, którzy uniknęli pojmania, personelu przygotowanego w okresie pokoju lub ludność cywilną mogłoby w znacznym stopniu utrudnić przeciwnikowi prowadzenie dalszych operacji oraz zachowanie kontroli nad opanowanym terenem. W tym kontekście warto rozważyć doświadczenia austriackiej jednostki specjalnej Jagdkommando. W okresie zimnej wojny istotnym elementem szkolenia jej żołnierzy było przygotowanie do prowadzenia walki niekonwencjonalnej i tworzenia oddziałów partyzanckich. Ciekawym rozwiązaniem było pozostawienie żołnierzom, którzy pomyślnie ukończyli kurs podstawowy formacji możliwości powrotu do macierzystej jednostki w charakterze instruktora działań niekonwencjonalnych (Kudliński, 2010: 6-13).

Ważnym aspektem hipotetycznej operacji obronnej jest również przeciwdziałanie operacjom specjalnym przeciwnika prowadzonym na własnym terytorium. Praktycznie wszystkie państwa europejskie dysponują obecnie siłami specjalnymi, które w wypadku wojny mogą prowadzić działania ofensywne na terytorium przeciwnika. Wszystkie uwagi odnośnie możliwości użycia polskich wojsk specjalnych w takim samym stopniu odnoszą się do analogicznych formacji przeciwnika. Stąd istotna staje się kwestia zabezpieczenia własnych wojsk, infrastruktury krytycznej oraz ludności cywilnej przed tego typu działaniami strony przeciwnej. Biorąc pod uwagę podobieństwa organizacyjne, sprzętowe i doktrynalne, wydaje się, iż formacje specjalne najlepiej nadają się do przeciwdziałania operacjom specjalnym przeciwnika. Wydaje się, iż w tą stronę zmierza częściowo rozwój JW Agat.

W ramach konwencjonalnej operacji obronnej wojska specjalne mogą również w szerokim zakresie udzielać wsparcia siłom konwencjonalnym. Może to na przykład przybrać postać pełnienia Bojowej Stużby Poszukiwawczo-Ratowniczej (ang. Combat Search\&Rescue - CSAR) i chociażby udzielania pomocy lotnikom zestrzelonym nad terenem kontrolowanym przez przeciwnika. Grupy żołnierzy wojsk specjalnych moga być również przydzielane do konwencjonalnych pododdziałów celem udzielenia specjalistycznego wsparcia. Przykładowo w trakcie działań w Iraku amerykańskie jednostki liniowe korzystały ze wsparcia snajperów i specjalistów w zakresie walki 
w budynkach z sił operacji specjalnych (West, 2006). Należy jednak założyć, iż w ramach konfliktu na pełną skalę, wojska specjalne będą raczej pełniły funkcję pomocniczą i uzupełniającą wobec wojsk konwencjonalnych, a kluczowym czynnikiem decydującym o ich użyteczności będzie zdolność do działania na terenie kontrolowanym przez przeciwnika.

\section{Wspieranie bezpieczeństwa wewnętrznego i pomoc społeczeństwu/operacje narodowe w czasie pokoju}

Ostatnim obszarem działalności SZ RP na gruncie Strategii Obronności z 2009 r. jest wsparcie bezpieczeństwa wewnętrznego i pomoc społeczeństwu. W tym artykule do tej kategorii zostaną dołączone misje narodowe realizowane w trakcie pokoju poza granicami państwa (jako nieprzynależne do operacji obronnej terytorium RP, ani sojuszniczych operacji ekspedycyjnych). Ze względu na swe przeznaczenie oraz unikalne zdolności wojska specjalne posiadają szczególne warunki, aby wnieść unikatowy wkład w bezpieczeństwo wewnętrzne państwa.

Potencjalnie najważniejszą misją, którą mogą w tym obszarze realizować jednostki specjalne jest wsparcie sił bezpieczeństwa wewnętrznego (przede wszystkim Policji) w zwalczaniu zagrożenia terrorystycznego. $Z$ uwagi na zaangażowanie Polski w operacje prowadzone w ramach tzw. globalnej wojny z terroryzmem groźbę ataku ze strony islamistycznych organizacji terrorystycznych należy traktować poważnie. Dotychczasowe doświadczenia pokazuję, iż poziom organizacyjnego i taktycznego wyrafinowania ataków terrorystycznych rośnie. Przyjmują one nie tylko postać ataków lotniczych i bombowych (np. w USA - 2001 r., Madrycie - 2004 r. czy Londynie - 2005 r.) ale także masowych incydentów z udziałem zakładników (Moskwa - 2002 r., Biesłan - 2004 r., Algieria - 2012 r.) czy zakrojonych na szeroką skalę ataków z użyciem broni palnej i materiałów wybuchowych (Mumbaj - 2008 r.). Przeciwdziałanie tym formom aktów terrorystycznych wymaga użycia specjalnie przygotowanych sił zdolnych do podjęcia tak skomplikowanych operacji jak ratowanie zakładników czy neutralizacja napastników na drodze bezpośredniej walki prowadzonej w terenie zurbanizowanym.

W Polsce za przeciwdziałanie terroryzmowi odpowiedzialne są formacje podległe Ministerstwu Spraw Wewnętrznych, w pierwszej kolejności Policja (ważną rolę odgrywa tu Agencja Bezpieczeństwa Wewnętrznego, jednak bardziej w aspekcie wywiadowczym). W strukturach Policji funkcjonuje rozbudowany system pododdziałów antyterrorystycznych, jednak poziom jego gotowości do reakcji na poważne incydenty terrorystyczne jest przedmiotem publicznie wyrażanych wątpliwości (Rzecznik, 2012; Ćwieluch, 2013). Abstrahując od rozważań nad kondycją policyjnych sił AT (których na gruncie publicznie dostępnej wiedzy nie da się jednoznacznie rozstrzygnąć) należy zauważyć, iż wojska specjalne dysponują znaczącym potencjałem zdolnym do wsparcia sił bezpieczeństwa wewnętrznego w działaniach antyterrorystycznych. Przede wszystkim należy pamiętać, iż $J W$ GROM została powołana z myślą o realizacji tego typu zadań. Ponadto, w porównaniu z jednostkami podległymi MSW, GROM dysponuje liczną kadra, zorganizowaną w zgrane i kompletne zespoły bojowe (z odpowiednimi środkami wsparcia i zabezpieczenia działań), doświadczeniem bojowym z realnych 
operacji prowadzonych poza granicami państwa oraz bogatym arsenałem specjalistycznego uzbrojenia i wyposażenia. Przydatność wojsk specjalnych dla realizacji operacji antyterrorystycznych dostrzegł ustawodawca, wprowadzając w ostatnich latach regulacje prawne umożliwiające użycie jednostek SZ RP do wsparcia działań Policji (Chloupek, 2012a: 20-30).

W ramach wsparcia bezpieczeństwa wewnętrznego wojska specjalne mogą również zostać wykorzystane do wzmocnienia ochrony ważnych osób i obiektów na terytorium państwa, jak i poza jego granicami. Może to dotyczyć wsparcia działań ochronnych prowadzonych przez Biuro Ochrony Rzqdu i Żandarmerię Wojskowq wobec osób sprawujących ważne funkcje państwowe lub ochrony szeroko pojętej infrastruktury krytycznej. Zasadniczo, zadania te spoczywają na innych formacjach niż SZ RP, jednak (podobnie jak w przytoczonym wcześniej przykładzie operacji antyterrorystycznych) w sytuacji ponadprzeciętnego zagrożenia może pojawić się zapotrzebowanie na specyficzne zdolności, którymi dysponują wojska specjalne. Przykładem tego typu sytuacji może być zaangażowanie żołnierzy $J W G R O M$ do ochrony osobistej ministra obrony narodowej w trakcie jego podróży do Afganistanu i Iraku.

Wkład wojsk specjalnych w zabezpieczenie ważnych osób i/lub obiektów nie musi się ograniczać do zapewniania fizycznej ochrony. Użytecznym instrumentem testowania systemów bezpieczeństwa mogą być działania z zakresu tzw. red teaming, tzn. prowadzenie symulowanych ataków (najlepiej odwzorowujących jak najdokładniej sposób działania potencjalnego przeciwnika) na chronione obiekty w celu wykrycia słabych punktów zabezpieczeń. $Z$ racji tego, iż do zadań wojsk specjalnych należy prowadzenie operacji ofensywnych przeciwko analogicznym celom po stronie przeciwnika, ich żołnierze są szczególnie wykwalifikowani do prowadzenia tego typu weryfikacji. Jako przykład takich działań można podać dokonania tzw. Red Cell kierowanej przez kmdr. Richarda Marcinko (twórcę i pierwszego dowódcę SEAL Team 6 - obecnie Naval Special Warfare Development Group, elitarnej jednostki kontrterrorystycznej Marynarki Wojennej Stanów Zjednoczonych), której zadaniem była weryfikacja stanu zabezpieczenia baz US Navy (Marcinko, Weisman, 2012: 427-472). Innym przejawem tego rodzaju operacji były działania norweskiej jednostki specjalnej FSK w amerykańskiej bazie w Keflaviku na Islandii (Chloupek, 2012c: 31).

Jak już wielokrotnie zaznaczono, żołnierze wojsk specjalnych dysponują szerokim wachlarzem unikatowych umiejętności. Ten potencjał może zostać wykorzystany nie tylko we właściwych operacjach specjalnych, ale także w ramach szkolenia partnerów narodowych i zagranicznych. W ramach tego typu działań personel wojsk specjalnych może prowadzić szkolenia specjalistyczne w wielu dziedzinach, jak np. skoki spadochronowe, nurkowanie, działania snajperskie, patrolowe itd. Ich odbiorcami mogą być żołnierze jednostek pozostałych rodzajów sił zbrojnych lub funkcjonariusze służb bezpieczeństwa wewnętrznego. Można nawet postulować utworzenie na bazie komponentów podległych DWS ,centrów doskonalenia” (ang. Centre of Excellence) w wybranych dziedzinach specjalistycznych, działających na rzecz całych SZ, czy szerzej systemu bezpieczeństwa państwa. W aspekcie zewnętrznym szkolenie żołnierzy i funkcjonariuszy z innych państw może być użytecznym narzędziem rozwoju współpracy (np. w ramach dyplomacji wojskowej), jak również może służyć budowaniu zdolności sojuszników i partnerów (np. w ramach misji doradztwa/wsparcia wojskowego). 
W ostatnich latach misje doradztwa wojskowego stały się ważnym narzędziem kształtowania bezpieczeństwa międzynarodowego przez NATO i UE.

Innym istotnym obszarem działalności wojsk specjalnych wielu państw jest ochrona własnych obywateli w sytuacjach kryzysowych poza granicami państwa. Warto pamiętać, iż pierwotnym zamysłem przyświecającym utworzeniu jednostki GROM było uzyskanie zdolności do ochrony życia obywateli polskich znajdujących się w strefach konfliktów. Doskonałą ilustracją tej funkcji sił operacji specjalnych może być ewakuacja obywateli szeregu państw NATO z terytorium Libii po wybuchu wojny domowej w tym państwie w $2011 \mathrm{r}$. W większości przypadków była ona zabezpieczana przez żołnierzy jednostek specjalnych. Jednym z najbardziej upublicznionych przykładów była ewakuacja brytyjskich pracowników koncernów naftowych, rozproszonych na pustynnych obszarach Libii, przez operatorów SAS (Gawęda, 2012). Operatorzy jednostek specjalnych są również często angażowani do ochrony personelu i placówek dyplomatycznych w strefach konfliktów. Dowodem na potrzebę tego typu specjalistycznej ochrony może być zamach na ambasadora RP w Iraku Edwarda Pietrzyka (2007 r.) lub atak na konsulat USA w Benghazi (2012 r.). Na polskim gruncie, żołnierze GROM byli angażowani do ochrony polskich placówek dyplomatycznych w Afganistanie i Iraku. Ciekawych doświadczeń w operacjach tego typu może również dostarczyć analiza działań jednostki specjalnej czeskiej policji URNA służących ochronie personelu dyplomatycznego tego państwa w strefach konfliktów (Chloupek, 2012b: 32-35).

W wielu państwach żołnierze wojsk specjalnych są również wykorzystywani do wsparcia i zabezpieczenia operacji prowadzonych przez służby wywiadowcze. Do wiadomości publicznej przedostały się informacje nt. wydzielonych zespołów przeznaczonych do tego typu zadań funkcjonujących w brytyjskiej SAS (tzw. E Squadron) oraz australijskim SASR (E Squadron; Urban, 2012; Epstein, Welch, 2012). Pojawiły się również doniesienia o utworzeniu przez CIA służby odpowiedzialnej za ochronę jej personelu w strefach szczególnie niebezpiecznych. Zadaniem tego typu zespołów jest przede wszystkim zapewnienie bezpieczeństwa oficerom wywiadu w trakcie szczególnie niebezpiecznych operacji na wrogim terytorium (Miller, Tate, 2012). Chociaż skala działań polskiego wywiadu jest mniejsza niż jego amerykańskich czy brytyjskich odpowiedników, to jednak nie można wykluczyć potencjalnej użyteczności wojsk specjalnych dla wsparcia jego operacji.

Ważnym aspektem pokojowej działalności SZ RP jest wydzielanie sił w charakterze narodowych kontrybucji do stałych sił szybkiego reagowania NATO (Sity Odpowiedzi NATO, ang. NATO Response Force - NRF) oraz UE (Grup Bojowych UE, ang. EU Battle Groups). Cechy, które decydują o użyteczności wojsk specjalnych w sojuszniczych operacjach reagowania kryzysowego (opisane wcześniej), tak na płaszczyźnie polityczno-strategicznej, jak i zdolności operacyjnych, czynią ten rodzaj wojsk dobrym kandydatem do wystawienia elementów składowych polskich kontyngentów w ramach wspomnianych wcześniej sił. Obecnie trwają przygotowania do certyfikacji DWS jako sojuszniczego połączonego dowództwa operacji specjalnych, zdolnego do kierowania wielonarodowymi operacjami specjalnymi w ramach NATO. Przewiduje się, iż począwszy od 2014 roku, DWS byłby zdolny do dowodzenia sojuszniczymi operacjami specjalnymi, a w 2016 i 2017 r. miałby wystawić kontyngent do Sit Odpowiedzi NATO 
(Kwasek, 2012: 88). Ogólny trend rosnącej roli sił operacji specjalnych w planowaniu sojuszniczym wskazuje na rosnącą wartość wkładu Wojsk Specjalnych we wspólne przedsięwzięcia.

$$
* * *
$$

Uwarunkowania przyszłego rozwoju polskich Wojsk Specjalnych można rozpatrywać z perspektywy szans, wyzwań, ryzyk i zagrożeń, które rysują się przed tym rodzajem sił zbrojnych. W naturalny sposób czynniki te mają swoje źródła zarówno wewnątrz struktury Wojsk Specjalnych, jak i szerzej SZ RP, w uwarunkowaniach szeroko pojętej polityki bezpieczeństwa RP, jak również w międzynarodowym środowisku bezpieczeństwa państwa.

Jedną z kluczowych szans w perspektywie dalszego rozwoju Wojsk Specjalnych jest ich silna pozycja instytucjonalna w obecnej strukturze SZ RP. Utworzenie Dowództwa Wojsk Specjalnych i nadanie statusu osobnego rodzaju sił zbrojnych pozwoliło na rozwiązanie wielu istotnych problemów organizacyjnych, które do tej pory stanowiły poważną przeszkodę dla rozwoju potencjału jednostek specjalnych. Przed rokiem 2007 jednostki, które następnie znalazły się w podporządkowaniu nowego dowództwa były rozproszone w różnych miejscach struktury Wojska Polskiego. W opinii większości obserwatorów, taki układ nie pozwalał na pełne wykorzystanie ich potencjału. Decydował o tym m.in. brak spójnej koncepcji użycia sił specjalnych oraz podporządkowanie „ogólnowojskowym” normom szkoleniowym i sprzętowym (z natury nie uwzględniającym specyfiki tego rodzaju wojsk). Jednostka GROM, znajdująca się w bezpośrednim podporządkowaniu Sztabu Generalnego WP znajdowała się pod tym względem w znacznie lepszej pozycji niż jednostki podporządkowane rodzajom sił zbrojnych (1 PSK oraz Formoza) (Odpowiednie, 2012). Status GROM jako najlepszej polskiej jednostki specjalnej jest $\mathrm{w}$ dużej mierze pochodną autonomii organizacyjnej, szkoleniowej i sprzętowej, z której formacja ta mogła korzystać praktycznie od początku swego funkcjonowania. Jednak, jak zauważa były dowódca GROM gen. Roman Polko, możliwości rozwoju jednostki były w dużej mierze pochodną osobistej pozycji poszczególnych dowódców i ich zdolności do skutecznego „lobbowania” kierownictwa SZ i MON na rzecz konkretnych rozwiązań. Tym samym rozwój jednostki miał wyraźnie cykliczny charakter, powiązany ze zmianami dowództwa (Polko, 2008b: 183-186). Warto pamiętać, iż dowódcy pozostałych jednostek specjalnych nie mieli takiego dostępu do zwierzchników i w konsekwencji możliwości forsowania swoich projektów.

Powołanie Dowództwa Wojsk Specjalnych i nadanie Wojskom Specjalnym statusu osobnego rodzaju sił zbrojnych doprowadziło do uporządkowania tej sytuacji. Zgromadzenie wszystkich jednostek specjalnych w jednej strukturze pozwoliło na standaryzację szkolenia, taktyki oraz wyposażenia, tak aby maksymalnie ułatwić wspólne operacje. W jego ramach doszło również do rozbudowy zaplecza umożliwiającego planowanie, przeprowadzanie i zabezpieczenie operacji specjalnych na znacznie większą skalę niż było to możliwe do tej pory. Powstał jeden ośrodek odpowiedzialny za programowanie rozwoju wojsk specjalnych oraz reprezentowanie ich interesów w ramach procesu formułowania i wykonywania polityki obronnej. Jak każda duża organizacja, 
Wojsko Polskie jest areną wewnętrznej rywalizacji o zasoby, prestiż i realizację różnych koncepcji. Do 2007 r. jednostki specjalne miały stosunkowo słabą pozycję w ramach tego procesu. Powstanie DWS zinstytucjonalizowało ich pozycję jako samodzielnego i liczącego się aktora w procesie decyzyjnym. W ramach nowego rodzaju sił zbrojnych jedna instytucja jest odpowiedzialna za planowanie długofalowego rozwoju wojsk specjalnych, bieżącą realizację oraz dowodzenie operacyjne wojskami. W tym kontekście warto się zastanowić czy doświadczeń tych nie można by przenieść na grunt służb podległych m.in. Ministerstwu Spraw Wewnętrznych. Obecnie różnego rodzaju formacje specjalne funkcjonują w ramach Policji, Straży Granicznej, ABW, BOR, Stużby Więziennej, Stużby Ochrony Kolei i Urzędów Kontroli Skarbowej. Przewiduje się, iż w wypadku konieczności przeprowadzenia operacji na dużą skalę, celowe byłoby łączenie potencjału tych zespołów. Może celowe byłoby stworzenie np. w ramach MSW jednego ośrodka odpowiedzialnego nie tyle za dowodzenie komórkami specjalnymi, ale za unifikację standardów ich szkolenia, taktyki i wyposażenia w celu zapewnienia interoperacyjności.

Ważnym czynnikiem warunkującym rozwój WS jest polityka NATO w tym obszarze. Jak już wcześniej zaznaczono, pod wpływem doświadczeń ostatnich konfliktów zbrojnych, Sojusz kładzie duży nacisk na rozwój Sit Operacji Specjalnych. Wiele państw członkowskich przyjęło model odrębnej struktury odpowiedzialnej za dowodzenie tego typu siłami (najczęściej w formie osobnego dowództwa operacji specjalnych). Stanowi to poważny impuls dla docenienia znaczenia i dalszego rozwoju polskich wojsk specjalnych. Warto również pamiętać o znaczeniu doświadczeń operacji irackiej. Na początku pierwszej dekady XXI w. kierownictwo Sił Zbrojnych i resortu obrony zdawało się nie doceniać przydatności jednostek specjalnych. Dokonania GROM w trakcie operacji w regionie Zatoki Perskiej i bezpośrednio w Iraku oraz ich bardzo pozytywny odbiór przez sojuszników odegrały dużą rolę w zmianie tego stanu rzeczy (Rybak, 2009). Na przestrzeni ostatnich ok. 10 lat stosunek kreatorów polskiej polityki obronnej do wojsk specjalnych uległ istotnemu przeobrażeniu (o pozytywnym dla tego rodzaju wojsk charakterze). Można przyjąć, iż jednym z istotnych czynników, które o tym zadecydowały były opinie i sugestie sojuszników. Swoistym ukoronowaniem tej reorientacji stało się powołanie DWS oraz podjęcie decyzji o uczynieniu Sit Operacji Specjalnych jednym z obszarów polskiej specjalizacji w ramach NATO. Dążenie do osiagnięcia przez DWS statusu sojuszniczego dowództwa operacji specjalnych oraz przyjęcia roli „państwa ramowego" w tym obszarze stanowi potężny impuls na rzecz rozwoju WS.

Należy pamiętać, iż polityka zagraniczna RP oraz międzynarodowe środowisko bezpieczeństwa państwa stwarzają szanse dla rozwoju Wojsk Specjalnych poprzez generowanie zapotrzebowania na ich unikalne zdolności. Rosnąca aktywność dyplomatyczna, gospodarcza i społeczno-kulturowa w różnych częściach świata (zarówno oficjalna - w wykonaniu funkcjonariuszy państwowych, jak i prywatna) często ma miejsce w strefach niestabilnych lub wprost na obszarach konfliktów zbrojnych. Generuje to zapotrzebowanie na siły zdolne do zabezpieczenia tego typu działalności, przeprowadzenia ewakuacji lub operacji ratowniczej w wypadku zagrożenia. Przykładem tego typu sytuacji może być chociażby porwanie polskiego inżyniera w Pakistanie. W tym wypadku jednak nie zdecydowano się na interwencję wojsk specjalnych ze 
względu na niesprzyjające warunki i wysoki poziom ryzyka, co równocześnie pokazuje ograniczenia, na jakie napotyka prowadzenie operacji specjalnych. Realność zagrożenia terrorystycznego terytorium i obywateli RP jest poważnym czynnikiem podnoszącym wartość wojskowego potencjału antyterrorystycznego w oczach decydentów oraz opinii publicznej i decydującym o jego utrzymywaniu oraz dalszym rozwoju.

Wśród kluczowych wyzwań stojących obecnie przed Wojskami Specjalnymi należy zwrócić uwagę na trzy kwestie: wypracowanie właściwej struktury wewnętrznej, umocowanie w systemie reagowania kryzysowego oraz rozbudowę ilościową. Wojska Specjalne są najmłodszym rodzajem sił zbrojnych w SZ RP i siłą rzeczy ich docelowa struktura wewnętrzna i koncepcja funkcjonowania jest wciąż w fazie kształtowania się. Kluczowym zagadnieniem jest wypracowanie „podziału pracy” między poszczególnymi jednostkami, tzn. określenie ich obszaru zadaniowego oraz miejsca w systemie wojsk specjalnych. Przy zachowaniu podziału na cztery jednostki bojowe (GROM, Komandosów, Formozę i Agat) logiczne wydaje się przyjęcie przez każdą z nich określonej specjalizacji (naturalnie przy rozwoju wszechstronnych zdolności do wzajemnego uzupełniania się i pewnej wymienności funkcji). Pojawiają się jednak głosy sugerujące, iż przyjęto strategię ,unifikacji” wszystkich jednostek, której celowość budzi poważne wątpliwości (Właściwe, 2012). Osobną kwestię stanowi wyzwanie stworzenia stosownego zaplecza i wsparcia dla operacji specjalnych w postaci elementów dowodzenia, logistycznych, rozpoznawczo-wywiadowczych i transportu (zwłaszcza lotniczego).

Efektywne wykorzystanie potencjału wojsk specjalnych wymaga wypracowania podstaw prawno-organizacyjnych oraz właściwych procedur dla ich użycia w sytuacjach kryzysowych, zarówno na terytorium państwa, jak i poza jego granicami. Jak już wcześniej wspomniano, przyjęto wiele regulacji prawnych mających umożliwić użycie wojskowych jednostek specjalnych dla wsparcia sił podległych MSW w sytuacji zagrożenia terrorystycznego. W praktyce jednak, ścieżka decyzyjna jest skomplikowana i długotrwała (Chloupek, 2012a). Ponadto Polska jest uczestnikiem europejskiego programu $A T L A S$, którego istotą jest zapewnienie interoperacyjności policyjnych jednostek antyterrorystycznych $\mathrm{z}$ różnych państw, tak aby mogły one udzielać sobie nawzajem wsparcia $\mathrm{w}$ wypadku poważnych incydentów terrorystycznych. Jednym z wprost sformułowanych celów tej inicjatywy jest wyeliminowanie potrzeby angażowania sił wojskowych do działań wewnętrznych (Chloupek, 2010a: 38-46). Źródłem wątpliwości są również przepisy, które miałyby regulować zasady użycia siły przez jednostki skierowane do zwalczania zagrożenia terrorystycznego na terytorium RP i ich potencjalne niedopasowanie do specyfiki taktyki przez nie stosowanej. Przy planowaniu reformy wojsk specjalnych, często postulowano bezpośrednie podporządkowanie jednostek specjalnych pod najwyższe organy kierujące zarządzaniem kryzysowym w celu efektywnego użycia w operacjach reagowania kryzysowego na własnym terytorium, jak i za granicą (powołując się niejednokrotnie na przykład brytyjski) (Polko, 2008b: 180-204; Polko, 2008a).

Kolejne wyzwanie stanowi potencjalnie szybka rozbudowa ilościowa Wojsk Specjalnych. Jak już wcześniej zaznaczono, na przestrzeni pięciu lat liczba zespołów bojowych uległa podwojeniu. W świetle jednej z najważniejszych zasad kultury organizacyjnej wojsk specjalnych, która mówi, iż ,wojska specjalne nie są produktem masowym", można stawiać pytania o wpływ tak dynamicznego rozwoju na gotowość 
bojową i poziom wyszkolenia. Tak szybka rozbudowa struktur w sposób naturalny musi (choćby przejściowo) rodzić trudności z absorpcją nowego personelu, utrzymaniem wysokich standardów reżimu szkoleniowego i utrzymaniem poziomu gotowości bojowej. Ponadto, warto zwrócić uwagę, iż rozbudowa ilościowa wiąże się w konsekwencji z większą rotacją personelu. Pojawia się pytanie o należyte zagospodarowanie potencjału żołnierzy odchodzących ze służby w Wojskach Specjalnych. Mówiąc wprost, im więcej ludzi służy w jednostkach DWS, tym więcej potencjalnych „specjalnych wojskowych emerytów". Warto zastanowić się nad tym jak można by wykorzystać ich doświadczenie i umiejętności po odejściu ze służby. Jednym z praktykowanych na świecie rozwiązań jest praca w prywatnych firmach wojskowych, które często współpracują (mniej lub bardziej formalnie) z macierzystymi państwami. W tym kontekście warto nadmienić, iż w trakcie wspomnianej już operacji ewakuacji obywateli brytyjskich z Libii rolę odegrały również prywatne firmy ochraniające brytyjskich pracowników firm wydobywczych (Gawęda, 2012).

Rozważając ryzyka związane z dalszym rozwojem Wojsk Specjalnych należy pamiętać o dwóch najistotniejszych czynnikach, które warunkują ich obecną pozycję i dynamiczną rozbudowę. Są to: doskonałe dostosowanie wojsk specjalnych do warunków prowadzonych obecnie konfliktów asymetrycznych oraz trendy panujące obecnie w planowaniu obronnym NATO, przekładające się na inicjatywy i sugestie promujące rolę sił operacji specjalnych. Osłabienie źródeł obu tendencji mogłoby się przełożyć na obniżenie rangi Wojsk Specjalnych w ramach Systemu Obronnego RP. Jak już wcześniej wyjaśniono, użyteczność jednostek specjalnych jest najwyższa w trakcie konfliktów asymetrycznych, natomiast w warunkach konfliktu konwencjonalnego zauważalnie spada. Obecnie scenariusz użycia SZ RP w operacji ekspedycyjnej w warunkach konfliktu asymetrycznego jest faktycznie uważany za priorytetowy. Natomiast gdyby za bardziej prawdopodobny i w konsekwencji priorytetowy, uznano wariant konwencjonalnej operacji obronnej, rola i znaczenie wojsk specjalnych mogłyby ulec poważnemu ograniczeniu. Zagadnienie to wiąże się również z problemem przyszłości NATO i zaangażowania tej organizacji w reagowanie na kryzysy polityczno-wojskowe w rożnych częściach świata. Wobec postępującego kryzysu tożsamości i zdolności Sojuszu realne staje się pytanie, czy po zakończeniu zasadniczej operacji w Afganistanie w 2014 r. będzie się on nadal angażował w operacje reagowania kryzysowego poza obszarem traktatowym? W wypadku gdyby odpowiedź na nie była negatywna to, analogicznie jak w układzie narodowym, waga przywiązywana do rozwoju sił operacji specjalnych była zapewne zauważalnie mniejsza.

Kolejnym obszarem potencjalnego ryzyka jest zdolność pozyskiwania odpowiedniego personelu i możliwość rywalizacji z innymi formacjami spoza wojska. Jak już wcześniej podkreślono, ogólna pula osób z właściwymi predyspozycjami do służby $\mathrm{w}$ jednostkach specjalnych jest $\mathrm{w}$ danej populacji dość ograniczona. Należy przy tym zwrócić uwage, iż formacje o charakterze specjalnym są obecnie dynamicznie rozwijane nie tylko w wojsku, ale również w różnych służbach bezpieczeństwa wewnętrznego (np. Policji, Straży Granicznej itd.). Tym samym, potencjalnie może się pojawić między nimi rywalizacja o pozyskanie wartościowych kandydatów (Alexander, 2010: 77-78). Nie można także zapominać o atrakcyjnych warunkach finansowych, jakie osobom o odpowiednich predyspozycjach i/lub wyszkoleniu może zaoferować sektor 
prywatny (jak różne firmy zajmujące się szeroko pojętym bezpieczeństwem, czy wprost prywatne firmy wojskowe).

Pozostaje również kwestia relacji między rozbudową WS a szerszą modernizacją całości SZ RP. Obecnie w Polsce mamy faktycznie do czynienia z „wojskiem dwóch prędkości" przejawiającym się w podziale nie wąskie grono jednostek wysokiej gotowości, w których wyszkolenie i wyposażenie czyni się znaczne inwestycje oraz resztę potencjału, który pod względem środków na szkolenie oraz dostępności nowoczesnego wyposażenia pozostaje wyraźnie zapóźniony. Chociaż obecnie budżet WS wynosi zaledwie ok. 2,75\% ogólnego budżetu MON, to jednak może rodzić się pytanie, czy nacisk, jaki kładzie się obecnie na rozwój tego rodzaju sił zbrojnych, nie przyczyni się do pogłębienia tego podziału. Może to zachodzić nie tylko na płaszczyźnie czysto finansowej, ale także organizacyjnej oraz podejścia decydentów.

Odnośnie potencjalnych zagrożeń dla dalszego rozwoju wojsk specjalnych, to można zidentyfikować trzy ich obszary. Po pierwsze, jest to reforma systemu dowodzenia SZ RP. Wcześniej kilkukrotnie podkreślono wartość odrębności instytucjonalnej zapewnianej przez DWS i status odrębnego rodzaju sił zbrojnych. Obecne plany zakładają zatarcie podziału na rodzaje sił zbrojnych oraz podział dowodzenia bieżącego i operacyjnego sił zbrojnych między Dowództwo Generalne Rodzajów Sił Zbrojnych oraz Dowództwo Operacyjne Sit Zbrojnych. Podporządkowanie jednostek specjalnych jest tu niejasne, jednak prawdopodobnie funkcje DWS związane z planowaniem rozwoju i bieżącym dowodzeniem zostałyby przekazane do właściwego inspektoratu w ramach GDRSZ. Oznaczałoby to ponowne wpisanie jednostek specjalnych w struktury „ogólnowojskowe”, czyli odwrócenie całej logiki stojącej za reformą wprowadzającą osobny rodzaj sił zbrojnych. Zdolność nowej struktury do efektywnego wykorzystania potencjału wojsk specjalnych jest przedmiotem poważnych wątpliwości (Reforma, 2012). Kolejnym zagrożeniem dla WS może być ograniczenie wydatków na obronę. Co prawda regulacje ustawowe gwarantują określony poziom nakładów na obronę, jednak niedawne doświadczenia pokazują, iż realne redukcje wydatków mogą być dokonywane na drodze tzw. „kreatywnej księgowości”. Rodzi się zatem pytanie: jak długo w obecnych uwarunkowaniach gospodarczych Polska pozostanie jednym z nielicznych państw NATO, które nie zmniejszają wydatków wojskowych? Bez wątpienia szkodliwy dla WS jest swoisty klimat polityczno-medialny, który w ostatnich latach się wokół nich wytworzył. Chodzi o przypadki otwartych sporów między obecnymi i byłymi dowódcami jednostek podległych DWS odnośnie kierunku ich dalszego rozwoju. Chociaż na bazie publicznie dostępnej wiedzy nie można rozstrzygać o dokładnym charakterze i merytorycznej racji tych sporów, to jednak można domniemywać, iż mają one w znacznej mierze charakter personalno-ambicjonalny. Bez względu na racje zaangażowanych stron upublicznianie tego typu animozji z pewnością nie służy prawidłowemu rozwojowi Wojsk Specjalnych.

\section{Bibliografia}

About USSOCOM, United States Special Operations Command, http://www.socom.mil/Pages/AboutUSSOCOM.aspx, 16.01.2013. 
Alexander J. B. (2010), Convergence: Special Operations Forces and Civilian Law Enforcement, „JSOU Report” 10-6, The JSOU PressMacDill AirForce Base, Florida.

Chloupek I. (2010a), ATLAS pomoc i wspótpraca, „Special Ops Magazyn Ludzi Akcji”, nr 7-8.

Chloupek I. (2010b), Formoza, „Spec Ops Magazyn Ludzi Akcji”, nr 7-8.

Chloupek I. (2012a), GROM a Euro 2012, „Special Ops Magazyn Ludzi Akcji”, nr 3.

Chloupek I. (2012b), URNA za granica, „Special Ops Magazyn Ludzi Akcji”, nr 4.

Chloupek I. (2012c), 30 lat FSK, „Special Ops Magazyn Ludzi Akcji”, nr 6.

Cielma M. (2012), Wojska Specjalne A.D. 2012, „Nowa Technika Wojskowa”, nr 2.

Ćwieluch J. (2013), Terror bezsensu, „Polityka”, nr 4.

Dowództwo Wojsk Specjalnych (a), http://www.wojskaspecjalne.mil.pl/58-strona_glowna.html?ln=pl, 23.01.2013.

Dowództwo Wojsk Specjalnych (b), http://www.wojskaspecjalne.mil.pl/18-dws.html?ln=pl, 23.01.2013.

E Squadron, Elite UK Forces, http://www.eliteukforces.info/e-squadron/, 31.03.2013.

Epstein R., Welch D. (2012), Secret SAS teams hunt for terrorists, „The Sydney Morning Herald”, 13.03.2012, http://www.smh.com.au/national/secret-sas-teams-hunt-for-terrorists-20120312-1uwhy.html, 31.01.2013.

Gawęda M. (2012), Brytyjski wywiad i siły specjalne w Libii, „Armia Ilustrowany Magazyn Wojskowy", nr 1.

Joint Special Operations University SOF-Power Workshop A Way Forward for Special Operations Theory and Strategic Art, Report of Proceedings (2011), przygotowanie J. Celeski, https://jsou.socom.mil/Documents/SOF-Power\%20Workshop\%20Final.pdf, 26.01.2013.

JW GROM, http://www.wojskaspecjalne.mil.pl/19-jw_grom.html?ln=pl, 31.01.2013.

JW Formoza, http://www.wojskaspecjalne.mil.pl/21-jw_formoza.html?ln=pl, 31.01.2013.

JW Komandosów, http://www.wojskaspecjalne.mil.pl/20-jw_komandosow.html? $1 \mathrm{n}=\mathrm{pl}, 31.01 .2013$. JW Nil, http://www.wojskaspecjalne.mil.pl/78-jw_nil.html?ln=pl, 31.01.2013.

Kudliński J. (2010), Austriaccy łowcy, „Militarny Magazyn Specjalny Komandos”, nr 6.

Krugler A. (2009), Święto 1. Pułku Specjalnego Komandosów, „Spec Ops Magazyn Ludzi Akcji”, nr 11-12,

Krugler A. (2012), Pierwsze urodziny JW Agat, „Spec Ops Magazyn Ludzi Akcji”, nr 4.

Kwasek T. (2012), Wojska Specjalne po 5 latach, „Nowa Technika Wojskowa”, nr 7.

Marcinko R., Weisman J. (2012), Komandos, Kraków.

Miller G., Tate J. (2012), CIA's Global Response Staff emerging from shadows after incidents in Libya and Pakistan, „The Washington Post”, http://www.washingtonpost.com/world/national-security/cias-global-response-staff-emerging-from-shadows-after-incidents-in-libya-and-pakistan/ 2012/12/26/27db2d1c-4b7f-11e2-b709-667035ff9029_story_2.html, 31.01.2013.

Odpowiednie Struktury (2012), „Special Ops Magazyn Ludzi Akcji”, nr 1.

Palowski J. (2012), Projekt budżetu MON na 2013 rok, „Nowa Technika Wojskowa”, nr 10.

Polko R. (2008a), Alternatywne podejście do problematyki organizacji dowodzenia wojsk specjalnych SZ RP, w: Wizja Sił Zbrojnych RP, Biblioteka „Bezpieczeństwa Narodowego”, t. 2, http://www.bbn.gov.pl/portal/pl/335/1000/Wizja_Sil_Zbrojnych_RP.html, 31.01.2013.

Polko R. (2008b), GROMw działaniach przeciwterrorystycznych, Biblioteka „Bezpieczeństwa Narodowego", t. 6, Warszawa.

Reforma (2012), „Special Ops Magazyn Ludzi Akcji”, nr 6.

Rybak J. (2009), GROM.PL 2 Tajne Operacje polskich sit specjalnych, Warszawa. 
Rzecznik Praw Obywatelskich interweniuje w MSW (2012), „Special Ops Magazyn Ludzi Akcji”, nr 2.

Spulak jr. R. G. (2007), A Theory of Special Operations The Origin, Qualities, and Use of SOF, JSOU Report 07-7, Hurlburt Field.

Strategia Obronności Rzeczypospolitej Polskiej (2009), http://www.bbn.gov.pl/portal/p1/475/2826/ Strategia_Obronnosci_Rzeczypospolitej_Polskiej.html, 12.01.2013.

Strategia Rozwoju Systemu Bezpieczeństwa Narodowego RP 2022 (2013), http://www.mon.gov.pl/ pliki/File/strategia_obronnosci/SRSBN_RP_przyjeta090413.pdf, 28.05.2013.

The North Atlantic Treaty Organization Special Operations Forces Study (2008), North Atlantic Treaty Organization Special Operations Coordination Centre, http://www.nshq.nato.int/NSHQ/ GetFile/?File_ID=29, 12.01.2013.

Urban M. (2012), Inside story of the UK's secret mission to beat Gaddafi, „BBC News Magazine”, 19.01.2012, http://www.bbc.co.uk/news/magazine-16573516, 31.01.2013.

Wizja Sit Zbrojnych RP - 2030 (2008), http://www.wp.mil.pl/pliki/File/Wizja_SZRP_2030.pdf, 26.01.2013.

West B. (2006), No True Glory: A Frontline Account of the Battle for Fallujah, New York.

\title{
STRESZCZENIE
}

Na przestrzeni ostatnich dwóch dekad wojska specjalne stały się ważnym elementem systemów obronnych wielu państw, wnosząc istotny wkład w prowadzone operacje wojskowe oraz ogólny potencjał służący realizacji stawianych przed nimi zadań. Wynika to z unikalnych zdolności tego rodzaju wojsk, czyniących je szczególnie użytecznymi we współczesnym środowisku bezpieczeństwa międzynarodowego. Czynniki te zadecydowały również o daleko idącej ewolucji i dynamicznym rozwoju polskich Wojsk Specjalnych. Celem artykułu jest analiza użyteczności jednostek specjalnych dla realizacji zasadniczych misji Sil Zbrojnych RP (zapisanych w Strategii Obronności RP) oraz prezentacja perspektyw ich dalszego rozwoju (przez pryzmat szans, wyzwań, ryzyk i zagrożeń).

\section{ROLE OF SPECIAL FORCES IN DEFENCE SYSTEM OF REPUBLIC OF POLAND}

\begin{abstract}
In the last two decades special operations forces became an important component of many states' defence systems, providing important contributions to actual military operations, as well as to a general potential for the achievement of given objectives. It stems chiefly from unique capabilities of those forces, which make them especially useful in the current international security environment. Those factors proved to be decisive for the far reaching evolution and dynamic development of polish special forces. This article aims to analyse special operations forces' utility for the fulfilment of the Polish Armed Forces' basic missions (as stated in the Defence Doctrine), as well as to present perspectives for their further development (through the opportunities, challenges, risks and threats framework).
\end{abstract}

